Ambiente \& Água - An Interdisciplinary Journal of Applied Science
ISSN 1980-993X - doi:10.4136/1980-993X
www.ambi-agua.net
E-mail: ambi.agua@gmail.com

\title{
Degradation of the Textile Dye Reactive Black 5 by Basidiomycetes
}

\author{
ARTICLES doi:10.4136/ambi-agua.2464
}

Received: 29 Aug. 2019; Accepted: 30 Nov. 2019

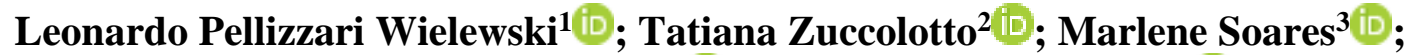 Liziê Daniela Tentler Prola ${ }^{3}$; Marcus Vinicius de Liz $^{3 * i D}$}

\author{
${ }^{1}$ Departamento de Bioquímica e Biologia Molecular. Universidade Federal do Paraná (UFPR), Avenida \\ Francisco H. dos Santos, no 100, CEP: 81531-980, Curitiba, PR, Brazil. E-mail: lpellizzari.w@gmail.com \\ ${ }^{2}$ Departamento Farmácia. Universidade Federal do Paraná (UFPR), Avenida Prefeito Lothário Meissner, n 632 , \\ CEP: 80210-170, Curitiba, PR, Brazil. E-mail: tatianazuccolotto1@ gmail.com \\ ${ }^{3}$ Departamento Acadêmico de Química e Biologia. Universidade Tecnológica Federal do Paraná (UTFPR), \\ Rua Deputado Heitor Alencar Furtado, n 5000, CEP: 81280-340, Curitiba, PR, Brazil. \\ E-mail: marlenesoares_br@yahoo.com.br, lizieprola@hotmail.com \\ *Corresponding author. E-mail: marcuslizutfpr@gmail.com
}

\begin{abstract}
Reactive Black 5 (RB5) is one of the synthetic reactive dyes most used in the textile industry, due to its solubility in water and reactive groups which form covalent bonds within the fiber. In the process of dyeing fabrics, however, it is estimated that $12-14 \%$ of dyes are released into the effluent. This work evaluated the biodegradation of RB5 dye, adsorbed in polyurethane foam, by basidiomycetes (Phanerochaete chrysosporium ATCC 24725, Pleurotus ostreatus and Pleurotus floridae). Results were evaluated considering the partial- or total medium discoloration, the adsorption capacity of the dye in the polyurethane foam (PUF) and the respirometric measurements. The results showed that Phanerochaete chrysosporium was able to partially degrade $50 \mathrm{mg} \mathrm{L}^{-1}$ of RB5 in pH 6.0, when cultivated in Petri dishes. When this microorganism was cultivated in PUF cubes saturated with RB5 solution $\left(50 \mathrm{mg} \mathrm{L}^{-1}, \mathrm{pH}\right.$ 6.0), $\mathrm{CO}_{2}$ production reached an accumulated value of $2.16 \mathrm{mg}$ on the fifteenth day, revealing the growth of the microorganism and consequently the contaminant degradation, which was used as the source of nutrients.
\end{abstract}

Keywords: biodegradation, phanerochaete chrysosporium, respirometric method.

\section{Degradação do corante têxtil Preto Reativo 5 por basidiomicetos}

\section{RESUMO}

O corante Preto Reativo 5 (RB5 - reactive black 5) é um dos corantes reativos sintéticos mais utilizados na indústria têxtil, devido à sua solubilidade em água e a grupos reativos que formam ligações covalentes com a fibra. No processo de tingimento de tecidos, no entanto, estima-se que $12-14 \%$ dos corantes sejam liberados para o efluente. O objetivo deste trabalho foi avaliar a biodegradação do corante RB5, adsorvido em espuma de poliuretano, por basidiomicetos (Phanerochaete chrysosporium ATCC 24725, Pleurotus ostreatus e Pleurotus florida). Os resultados foram avaliados considerando a descoloração parcial ou total do meio, a capacidade de adsorção do corante na espuma de poliuretano e a medida respirométrica. Os resultados mostraram que Phanerochaete chrysosporium foi o mais eficicente, sendo capaz de 
degradar parcialmente RB5 na concentração de $50 \mathrm{mg} \mathrm{L}^{-1} \mathrm{em} \mathrm{pH} \mathrm{6.0,} \mathrm{quando} \mathrm{cultivado} \mathrm{em}$ pacas de Petri. Quando este microrganismo foi cultivado em cubos de espuma de poliuretano saturada com solução de RB5 (50 mg L ${ }^{-1}, \mathrm{pH}$ 6.0) a produção de $\mathrm{CO}_{2}$ atingiu o valor acumulado de $2.16 \mathrm{mg}$ no décimo quinto dia, revelando o crescimento microbiano e a degradação do contaminante, que foi utilizado como fonte de nutrientes.

Palavras-chave: biodegradação, método respirométrico, Phanerochaete chrysosporium.

\section{INTRODUCTION}

The textile industry is one of the most important in the world. The global textile and clothing business in 2017 is estimated to be worth about US $\$ 4.395$ trillion. The current global apparel market is estimated at approximately US\$ 1.15 trillion, which makes up nearly $1.8 \%$ of the world Gross Domestic Product (GDP) (Textile Mates, 2018). In 2017, China was the topranked global textile exporter (37.2 percent of the global market share), followed by the European Union (with 23 percent of the global market share), and India (Statista, 2018).

The technology Dye Clean became a reference in the textile chemistry world market, consisting of dyeing cellulosic fibers with reactive dyes, such as Reactive Black 5 (RB5 - CAS Registry Number:12225-25-1/17095-24-8). Like all reactive dyes, the RB5 is highly soluble in water and difficult to degrade due to its polyaromatic (Fan et al., 2009). Another troubling fact is the production of aromatic amines due to the degradation of this type of dye with azo bonds, which are highly carcinogenic (Vilar et al., 2011), while also being considered highly recalcitrant, toxic and mutagenic substances for various aquatic species (Vedrenne et al., 2012).

Regarding the process of dyeing fabrics, there is an estimate that $12-14 \%$ of textile dyes are released into the effluent (Safa et al., 2011). These compounds cause visual pollution, changes in the micro-aquatic biota and photosynthetic processes, and bioaccumulation of toxic substances in aquatic organisms (Kunz et al., 2002). In addition, most of them are classified as toxic, mutagenic and carcinogenic for aquatic organisms and humans (Ahmad et al., 2011; Wang et al., 2014), consisting of a serious ecological problem. The reactive dyes are highly recalcitrant to conventional effluent treatment processes, which, although removing about $80 \%$ of the dyes, leave most adsorbed in the sludge (Kunz et al., 2002).

Microbial and enzyme immobilization have been extensively studied in the treatment of dye-based industrial effluents (Bilal et al., 2017), being known as a solid state (SS) cultivation/fermentation process. Polyurethane foam (PUF) is one of the substrates used for fungal SSF, because it increases enzyme production and substrate oxygenation, without causing shear stress to the biomass (Sharari et al., 2013).

White rot fungi (for example, Phanerochaete chrysosporium, Pleurotus sp, Trametes sp, Ganoderma sp) are among the most efficient microorganisms in the treatment of xenobiotic molecules, such as synthetic reactive dyes (Wesenberg et al., 2003). Their metabolic capacity to mineralize complex polymers, like lignin, is due to the secretion of non-specific enzymes, which includes Laccases (EC 1.10.3.2), manganese peroxidases (EC 1.11.1.13) and lignin peroxidases (EC 1.11.1.14).

Biodegradation can be assessed by microbial respiration. Respirometric methodologies are capable of evaluating the degradation process of organic waste based on the quantification of $\mathrm{CO}_{2}$ production or $\mathrm{O}_{2}$ consumption during metabolic activities. One of the most traditional methods used to assess biodegradation of organic wastes is the Bartha's respirometric assay (Bartha and Pramer, 1965). This is a titrimetric method which measures the $\mathrm{CO}_{2}$ trapped in a strong alkali after carbon mineralization by the microbial community present in the system (Bartha and Pramer, 1965; ABNT, 1999; Régo et al., 2014). Its use includes the assessment of the complete biodegradation of petroleum wastes, general compounds and organic fertilizers in 
soil such as sewage sludge (ABNT, 1999; Régo et al., 2014).

The aim of this study was to use polyurethane foam as matrix support to assess the biodegradation of the RB5 by fungi basidiomycetes $P$. ostreatus, $P$. floridae and $P$. chrysosporium ATCC 24725 in Bartha respirometers.

\section{MATERIAL AND METHOD}

\subsection{Analytical curve}

The RB5 dye stock solution was prepared by dissolving dye in Milli-Q water to the concentration of $100 \mathrm{mg} \mathrm{L}^{-1}$. For analytical curve, standard solutions ranging from 1.00 to 30.0 $\mathrm{mg} \mathrm{L}^{-1}$ of the dye were used, in parallel with a blank solution of water. The linear analytical calibration of the curve was furnished by a spectrophotometer UV-VIS (Varian Cary 50), in the scan range from 190 to $800 \mathrm{~nm}$. The wavelength of maximum absorption of the dye $(598 \mathrm{~nm})$ was used to monitor the concentration of the RB5 during the experiments. The calibration curve of the RB5 described with the equation $y=0.00262+0.02263 \mathrm{x}$ and the correlation coefficient was 0.99983 , indicating a good linearity.

\subsection{Preliminary studies}

To establish the better condition for RB5 adsorption in polyurethane foam, a full factorial design $2^{2}$ with central point, as shown in Table 1, was used to check the effect of experimental variables ( $\mathrm{pH}$ and dye concentration) in the adsorption of the RB5 in PUF. It was therefore determined that the dye concentrations to be used in the experiment were $\left(\mathrm{mg} \mathrm{L}^{-1}\right): 12.5,25$ and 50 .

Table 1. Full factorial design $2^{2}$ with central point, used to evaluate the effect of $\mathrm{pH}$ and the concentration of Reactive Black 5 dye in its adsorption in polyurethane foam.

\begin{tabular}{cccc}
\hline VARIABLE & Level (-1) & Level (0) & Level (+1) \\
\hline $\mathrm{pH}$ & 6 & 7 & 8 \\
Dye concentration $\left(\mathrm{mg} \mathrm{L}^{-1}\right)$ & 12.5 & 25 & 50 \\
\hline Experiment & & Dye concentration & $\mathbf{p H}$ \\
\hline 1 & - & - \\
2 & + & - \\
3 & - & + \\
4 & + & + \\
5 & 0 & 0 \\
6 & 0 & 0 \\
7 & 0 & 0 \\
\hline
\end{tabular}

The $\mathrm{pH}$ was adjusted using $\mathrm{NaOH} 0.1$ and $0.01 \mathrm{~mol} \mathrm{~L}^{-1}, \mathrm{HCl} 0.1$ and $0.01 \mathrm{~mol} \mathrm{~L}^{-1}$ solutions. The polyurethane foam was ceded by the Tecnotrater Group (Federal University of Paraná State - Brazil), having the following composition: polyethylene glycerol, 4.4- diphenylmethane diisocyanate, glycerol, water and Montmorillonite 3\%.

To achieve the maximum saturation of the dye in the matrix, adsorption studies were carried out introducing $100 \mathrm{mg}$ of PUF cubes $(1 \mathrm{~cm} \mathrm{x} 1 \mathrm{~cm} \mathrm{x} 1 \mathrm{~cm})$ into $50 \mathrm{~mL}$ of RB5dye solution, being shaken $(120 \mathrm{rpm})$ at room temperature $\left(25{ }^{\circ} \mathrm{C}\right)$, with $3 \mathrm{~mL}$ samples being collected at 15 and 30 minutes. However, as the experiment progressed, magnetic agitators were also used. Samples of the supernatant $(3 \mathrm{~mL})$ were collected at 10-minute intervals for 2 hours, in order to verify the saturation of the adsorbent.

The amount of dye taken up and the percentage of the dye removed by the PUF were calculated by applying Equations 1 and 2, respectively. 


$$
\begin{aligned}
& q=\frac{C_{o}-C_{f}}{m} \cdot V \\
& \% \text { Removal }=100 \cdot \frac{C_{o}-C_{f}}{C_{o}}
\end{aligned}
$$

In which " $\mathrm{q}$ " is the amount of dye adsorbed by the adsorbent $\left(\mathrm{mg} \mathrm{g}^{-1}\right)$, "Co" is the initial dye concentration placed in contact with the adsorbent $\left(\mathrm{mg} \mathrm{L}^{-1}\right)$, "Cf" is the dye concentration $\left(\mathrm{mg} \mathrm{L}^{-1}\right)$ after the batch adsorption procedure, " $\mathrm{m}$ " is the mass of adsorbent $(\mathrm{g})$ and " $\mathrm{V}$ " is the volume of dye solution (L).

\subsection{Microorganisms}

$P$. ostreatus, $P$. floridae and $P$. chrysosporium ATCC 24725 were cultivated on sterile Potato Dextrose Agar (PDA), in Petri dishes, at $26^{\circ} \mathrm{C} \pm 2^{\circ} \mathrm{C}$ for seven days, being kept at $+4^{\circ} \mathrm{C}$ for up to 30 days.

Inoculum was prepared by transferring an aliquot of the mycelium to a $250 \mathrm{~mL}$ Erlenmeyer flask containing $50 \mathrm{~mL}$ of sterile PDA, and incubating it for seven days at $26^{\circ} \mathrm{C} \pm 2^{\circ} \mathrm{C}$. The cell suspension was collected at the end of cultivation by adding $50 \mathrm{~mL}$ of sterile peptone water solution $\left(1 \mathrm{~g} \mathrm{~L}^{-1}\right), 0.2 \%$ of Tween $80,3 \mathrm{~g}$ of glass beads ( $3 \mathrm{~mm}$ diameter) and a magnetic bar. The suspension was subjected to agitation for 15 minutes, with sufficient rotation to promote cell dispersion. Cells were quantified using a Neubauer chamber and also by counting using Spread Plate technique, on PDA (Spier et al., 2006).

\subsection{Biodegradation of RB5 dye}

In order to optimize RB5 biodegradation by each fungus, a full factorial design $2^{2}$ with central point was performed in Petri dishes, as shown in Table 1 (the same conditions evaluated for adsorption of RB5 in PUF).

Biodegradation experiments were performed in $9 \mathrm{~mm}$ Petri dishes, containing $30 \mathrm{~mL}$ of the RB5 dye added with agar-agar (1.5\%), and adjusted pH. The inoculation occurred in wells located in the central part of each plate, with the addition of $100 \mu \mathrm{L}$ of the cellular suspension. The plates were then incubated at $26^{\circ} \mathrm{C} \pm 2{ }^{\circ} \mathrm{C}$. Radial growth was measured when one of the fungi reached the edge of the plate, in quadruple, using a digital caliper. The growth speed was determined by the division of the growth average observed by the number of days the experiment occurred $\left(\mathrm{mm} \mathrm{day}^{-1}\right)$ (Miyashira et al., 2010)

After measuring the growth rate, the Petri dishes were reincubated at $26^{\circ} \mathrm{C} \pm 2{ }^{\circ} \mathrm{C}$ for five days, to visually evaluate the total or partial discoloration of the media.

\subsection{Respirometric Method}

The respirometric assays were conducted considering the methodology described first by Bartha (1965), detailed at ABNT - NBR Method 14283/1999 (ABNT, 1999).

Each Bartha respirometer (ABNT, 1999) received $100 \mathrm{mg}$ of PUF, which were saturated with dye RB5 (50 $\mathrm{mg} \mathrm{L}^{-1}$ ) (sole carbon and nitrogen source to the microorganisms), and the $\mathrm{pH}$ was adjusted to 6.0 . This substrate was inoculated with $1 \mathrm{~mL}$ of the $P$. chrysosporium cell suspension. As the inoculum solution had $1.8 \times 10^{6}$ colony forming unity $(\mathrm{CFU}) \mathrm{mL}^{-1}$; this led to an initial cell concentration of $1.8 \times 10^{4} \mathrm{CFU} \mathrm{g}{ }^{-1} \mathrm{PUF}$.

The experiment took place for 15 days at room temperature $\left(25^{\circ} \mathrm{C}\right)$. The $\mathrm{CO}_{2}$ generated during microbial respiration was measured every 24 hours, by removing $\mathrm{KOH}$ solution $(0.2 \mathrm{~N})$ of the respirometric flask and replacing it daily. The residual $\mathrm{KOH}$ was titrated with standard $\mathrm{HCl}(0.1 \mathrm{~N})$ after addition of $1 \mathrm{~mL}$ of a solution of barium chloride to precipitate carbonate ions. Thus, the total amount of $\mathrm{CO}_{2}$ produced as a function of incubation time could be calculated and plotted. 
The values of $\mathrm{CO}_{2}$ were obtained according to Equation 3 (Régo et al., 2014):

$\mathrm{CO}_{2}(\mathrm{mg})=(\mathrm{A}-\mathrm{B}) \times 50 \times \mathrm{f}_{\mathrm{HCl}} \times 0.044$

Where " $\mathrm{A}$ " is the volume of $\mathrm{HCl}(0.1 \mathrm{~N})$ used to titrate the blank $(\mathrm{mL})$, " $\mathrm{B}$ " is the volume of $\mathrm{HCl}(0.1 \mathrm{~N})$ used to titrate the sample $(\mathrm{mL})$, and " $\mathrm{f}_{\mathrm{HCl}}$ ") values 50 and 0.044 were used to transform the $\mathrm{CO}_{2}$ from micromoles to milligrams (Régo et al., 2014).

\section{RESULTS AND DISCUSSION}

\subsection{Preliminary adsorption study}

Figure 1 illustrates the decay of sample absorbance during the factorial design study of the adsorption of the RB5 dye in PUF.
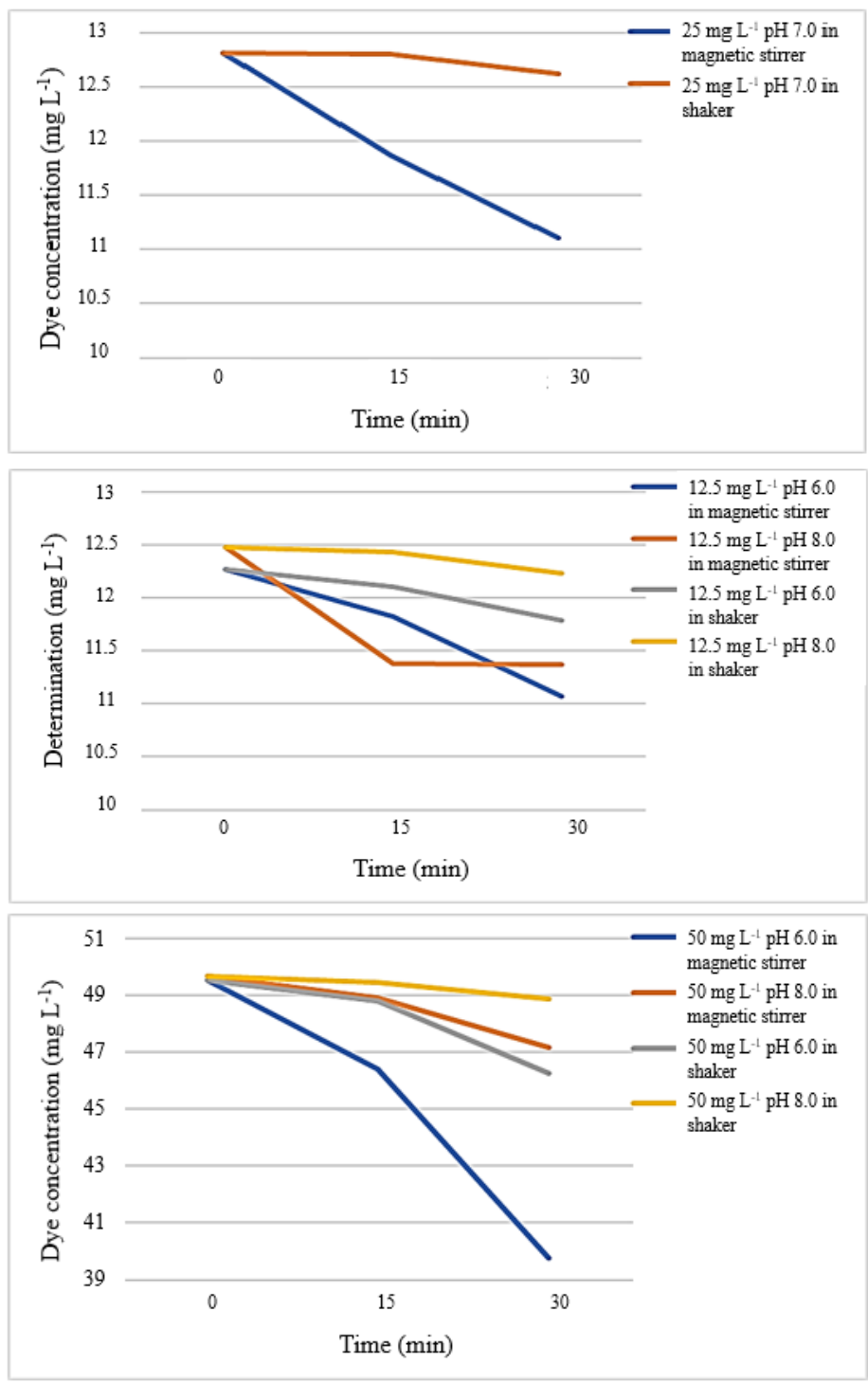

Figure 1. Absorbance variation of the samples during the factorial design study, checking the effect of $\mathrm{pH}$ and dye concentration in the adsorption of Reactive Black 5 in polyurethane foam. 
The best adsorption result was found using the magnetic stirrer, at $\mathrm{pH}$ 6.0. This variation was possible because the magnetic stirrer provided better agitation than the shaker, creating a whirlwind able to plunge and completely soak all the PUF cubes in the RB5 solution, improving the retention of textile dye. In relation to the $\mathrm{pH}$, it should be emphasized that $\mathrm{pH}$ changes the surface load of the adsorbent and the degree of ionization of different pollutants. This variable can change the adsorption process by decoupling functional groups present in the active sites of the adsorbent (Mall et al., 2014).

\subsection{Adsorption study of the RB5 due on the support.}

The adsorption experiment was conducted with $\mathrm{RB} 5$ dye at $50 \mathrm{mg} \mathrm{L}^{-1}$ in $\mathrm{pH} 6.0$ and $\mathrm{pH}$ 7.0. The maximum adsorption of RB5 dye in PUF occurred after 110 minutes of stirring in both $\mathrm{pH}$, as illustrated in Figure 2. The increase in the concentration of RB5 observed at 120 minutes indicates the desorption/adsorption equilibrium of the PUF was achieved, ending the experiment.

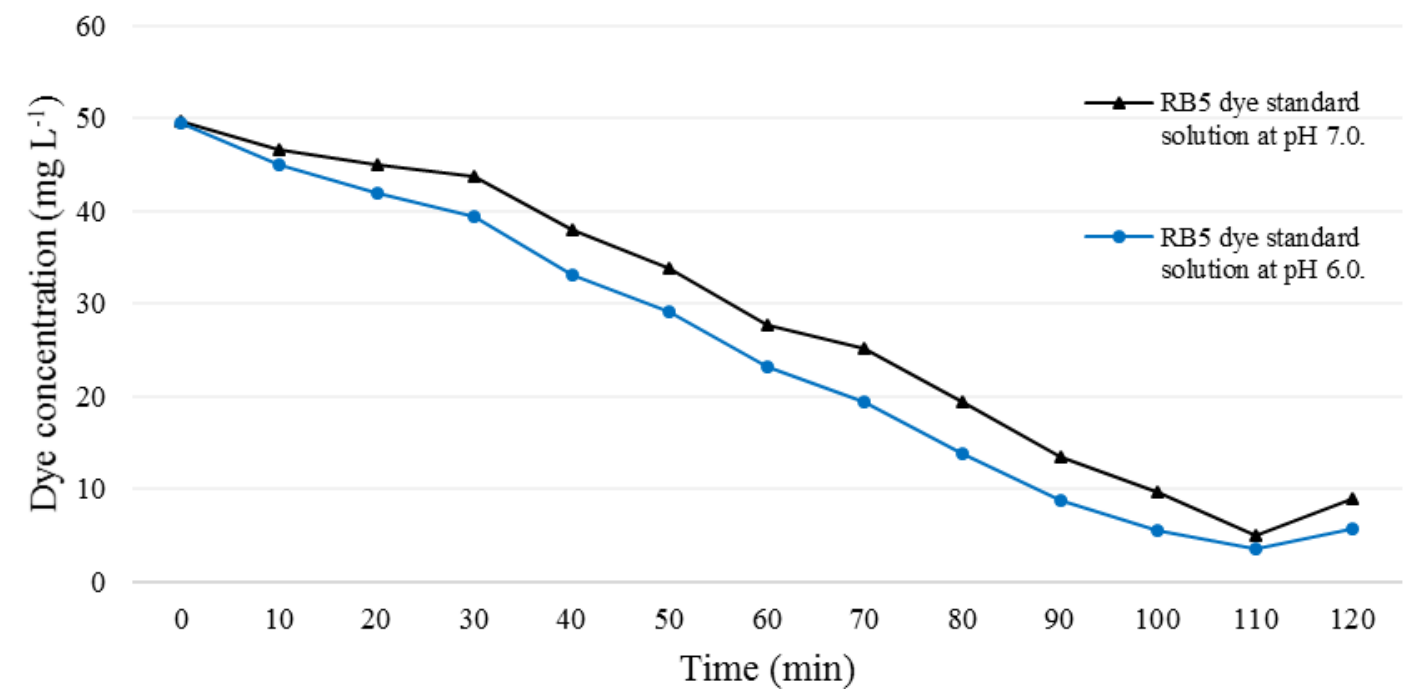

Figure 2. Adsorption efficiency of RB5 $50 \mathrm{mg} \mathrm{L}^{-1}$ in polyurethane foam, at $\mathrm{pH} 6.0$ and $\mathrm{pH}$ 7.0.

It was noted that the acidification of solution $(\mathrm{pH} 7.0$ to $\mathrm{pH} 6.0$ ) increases the adsorption of RB5 at PUF. This occurs precisely because of the dissociation of the ions present in the molecules of the textile dye and the ionization of the amino groups present in the PUF composition. However, this alternative wasn't addressed in this work, because after the adsorption of the dye in the PUF, this matrix was used as support and the textile dye as a nutrient source to the fungal culture, restricting the study to this range of work. Table 2 shows the percentage and quantification of RB5 dye $\left(50 \mathrm{mg} \mathrm{L}^{-1}\right)$ adsorbed by PUF.

Table 2. Results of the adsorption experiments mentioning the percentage and the quantity of Reactive Black 5 dye $\left(50 \mathrm{mg} \mathrm{L}^{-1}\right)$ adsorbed by polyurethane foam.

\begin{tabular}{lcc}
\hline & $\begin{array}{c}\text { Standard solution of RB 5 dye 50 mg } \\
\mathrm{L}^{-1} \text { without } \mathrm{pH} \text { adjustment }(\mathrm{pH} 7.0)\end{array}$ & $\begin{array}{c}\text { Standard solution of RB 5 dye 50 mg } \\
\mathrm{L}^{-1} \text { at } \mathrm{pH} 6.0\end{array}$ \\
\hline Concentration in the solution after & 5.2 & 3.8 \\
adsorption (mg L-1) & 10.4 & 7.6 \\
\% of mass RB5 in the solution & 44.7 & 46.2 \\
Adsorbed concentration (mg L-1) & 89.5 & 92.4 \\
$\%$ of RB5 adsorbed & 22.35 & 23.1 \\
\hline
\end{tabular}


The percentage of RB5 dye adsorption by polyurethane foam $(92.4 \%)$ is close to the values mentioned by Mori and Cassella (2009), which observed 93\% adsorption of violet crystal dye by PUF after 4 hours of stirring.

Góes et al. (2016) studied the adsorption of red dye samples by four modified polyurethane foams. PUF without cellulose adsorbed $83.8 \%$ of the dye, PUF with cellulose $75.7 \%$, PUF with modified cellulose (1:1) 90.9\%, and PUF with modified cellulose (3:1) 84.3\%.

The difference in the percentage of mass adsorbed in other works, when compared to the values obtained, may be due to factors such as the presence of different ionic groups in foams, the dimensions, densities and quantities of each piece used (which directly interferes with the surface area), the presence, quantity and arrangement of the ionizable groups in each foam, favoring the adsorption of several dye molecules or rendering unusable some reactive sites due to possible steric impediments, the dye-loading used, as well as the agitation conditions (temperature, concentration, $\mathrm{pH}$ and agitation speed) employed in each of the adsorption tests.

In the present work, the use of PUF with nitrogenous groups was favorable for the adsorption of the RB5 textile dye, which in aqueous solution has four negatively charged sulfate groups.

\subsection{Evaluation of radial growth and discoloration}

Cell suspensions were counted in Neubauer chamber and PDA plates, showing similar values (Table 3 ), indicating that fungi had viable cells in the inoculation.

Table 3. Number of fungi cells in the microbial suspensions used as inoculums.

\begin{tabular}{lcc}
\hline Fungi & Neubauer Chamber Count $\left(\mathrm{cel} \mathrm{mL} \mathrm{mL}^{-1}\right)$ & Count on PDA Plates $\left(\mathrm{CFU} \mathrm{mL}^{-1}\right)$ \\
\hline Pleurotus floridae & $9 \times 10^{5}$ & $1.1 \times 10^{5}$ \\
Pleurotus ostreatus & $3 \times 10^{5}$ & $1.5 \times 10^{5}$ \\
Phanerochaete chrysosporium & $1.8 \times 10^{8}$ & $1.2 \times 10^{8}$ \\
\hline
\end{tabular}

PDA: potato dextrose agar; CFU colony forming unity.

P. chrysosporium presented higher radial growth speed (RGS) than Pleurotus in all conditions studied, certainly due to the higher number of cells inoculated in the experiment (Table 3). While Pleurotus inoculum had $1.1-1.5 \times 10^{5}$ colony forming unity (CFU) (considering that $100 \mu \mathrm{L}$ were inoculated in the wells, at the center of the Petri dishes), $P$. chrysosporium inoculum had $1.2 \times 10^{8} \mathrm{CFU}$.

It's well known that the performance of a biological process is significantly influenced by the size and viability of the inoculum (Pirt, 1976). In this study RGS was probably influenced by factors such as change in nutrients, presence of inhibitors, spore germination, and concentration of the inoculum. Increasing inoculum size leads to an increase of the dividing (active) cell fraction, influencing growth rate $(\mathrm{dX} / \mathrm{dt})$ which is defined as: $\mathrm{dX} / \mathrm{dt}=\mu \mathrm{X}$ (where $\mu$ is the specific growth rate, and $\mathrm{X}$ is the inoculum size).

Although this is a difference in inoculation, Ottoni et al. (2013) also had better discoloration results of RB5 dye with $P$. chrysosporium (and Trametes versicolor) than with $P$. ostreatus. They also observed that in Petri dishes RB5 was decolorized only at a concentration equal or below $100 \mathrm{mg} \mathrm{L}^{-1}$, being the best results obtained at $50 \mathrm{mg} \mathrm{L}^{-1}$.

Comparing the genus $P$., it was observed that in most of the conditions $P$. ostreatus showed higher RGS than $P$. floridae. To $P$. floridae the higher RGS occurred at $\mathrm{pH} 6.0$, at the dye's lowest concentration $\left(7.36 \mathrm{~mm} \mathrm{day}^{-1}\right)$, while for $P$. ostreatus it occurred at $25 \mathrm{mg} \mathrm{L}^{-1}$, at $\mathrm{pH} 7$ (6.97 mm day $\left.{ }^{-1}\right)$. Muthukumaran et al. (2017) in their study showed that the P. ostreatus was able to remove $64 \%$ of the RB5 dye (Figure 3 ). 


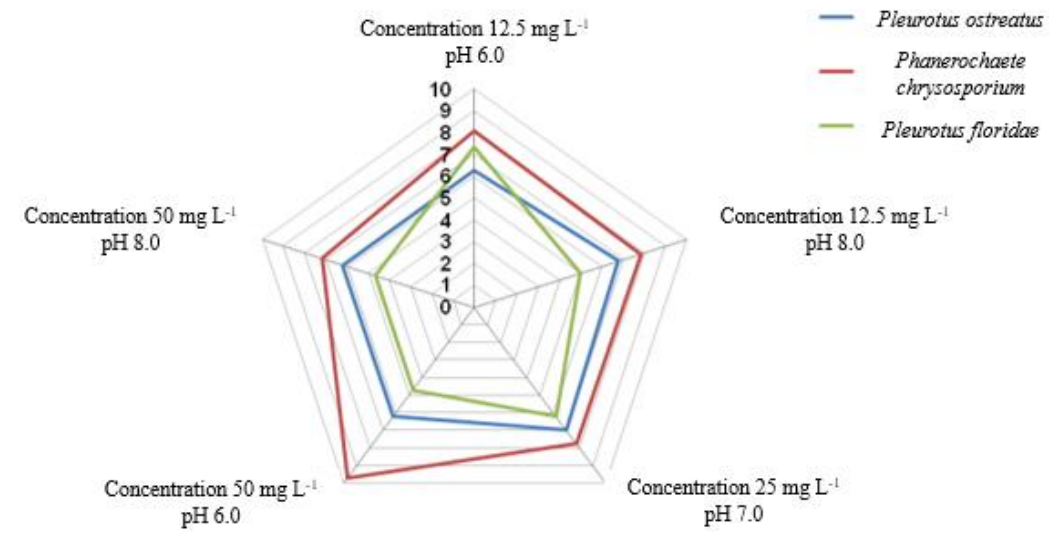

Figure 3. Radial growth speed $\left(\mathrm{mm} \mathrm{day}^{-1}\right)$ of $P$. ostreatus, $P$. floridae and $P$. chrysosporium cultivated on Reactive Black 5 dye solution solidified with agar-agar $\left(1.5 \mathrm{~g} \mathrm{~L}^{-1}\right)$ in Petri dishes.

Although it was visually observed that the color of the dye (chromophore group) in the cultivation media was not totally degraded, P. chrysosporium left them with a rose hue color, indicating their partial biodegradation. This color changing was also observed by Bonugli-Santos et al. (2013) using the fungus Peniophora sp.

Considering the partial degradation observed, RGS values obtained in P. chrysosporium cultivation were used to verify the existence of secondary interactions between the variables (dye concentration and $\mathrm{pH}$ ). According to the response surface chart (Figure 4), $P$. chrysosporium biodegrades RB5 more efficiently when cultivated in higher dye concentration (50 $\mathrm{mg} \mathrm{L}^{-1}$ ) and lower $\mathrm{pH}(6.0)$, as shown by a red color in surface chart. Thus, the biodegradation efficiency increases from green to red color, which used lower $\mathrm{pH}$ and higher concentrations.

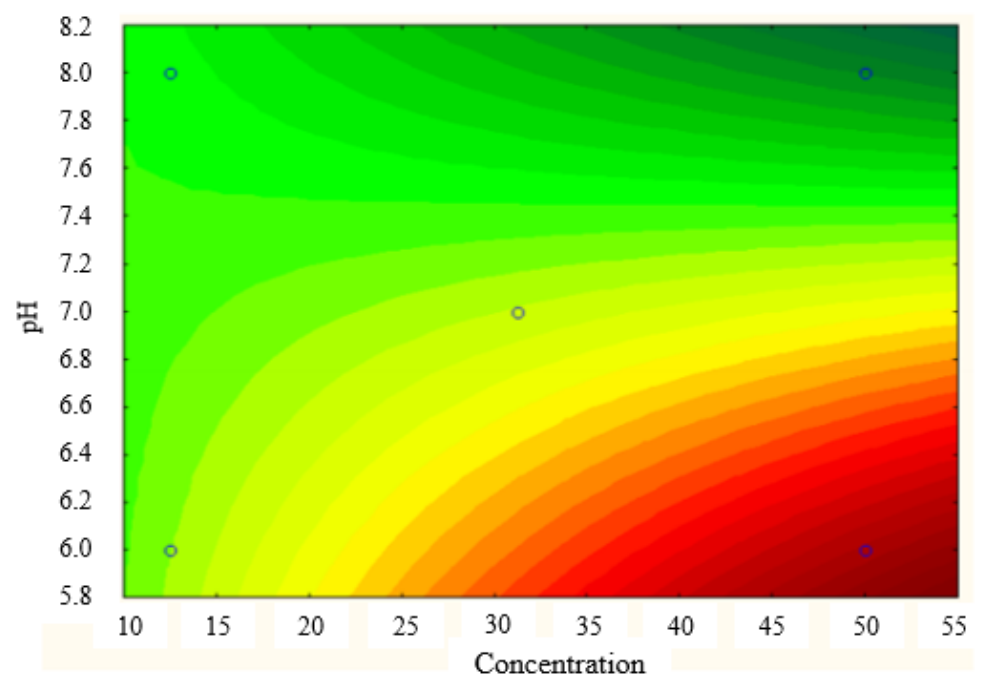

Figure 4. The response surfaces chart about $P$. chrysosporium ATCC 24725 growth when cultivated in Reactive Black 5 dye solutions in different $\mathrm{pHs}$, in Petri dishes.

Radha et al. (2005) observed that the growth of P. chrysosporium and the corresponding discoloration process were essentially controlled by the $\mathrm{pH}$ of the medium, depending on the nature of the substrate used. Their studies with different dyes showed better biodegradation results at lower $\mathrm{pH}(4.0-6.0)$. Permpornsakul et al. (2016) also concluded that a higher discoloration of RB5 by $P$. chrysosporium is obtained at $\mathrm{pH} 6.0$ than at $\mathrm{pH} 7.0$ or 8.0 , corroborating with this study. 


\subsection{Biodegradation Assay of Dye Reactive Black 5 Adsorbed on Polyurethane Foam}

After fifteen days of $P$. chrysosporium cultivation in PUF cubes, chromophore group of RB5 dye appears to have been completely degraded, as visually observed. This degradation may have occurred by lignin or manganese peroxidase activity, the production of which was reported to be greatly improved when $P$. chrysosporium was cultivated immobilized in PUF, then comparing with the production in conventional stationary liquid culture (Bilal et al., 2017). Figure 5 shows the concentration of accumulated $\mathrm{CO}_{2}$ produced during this experiment.

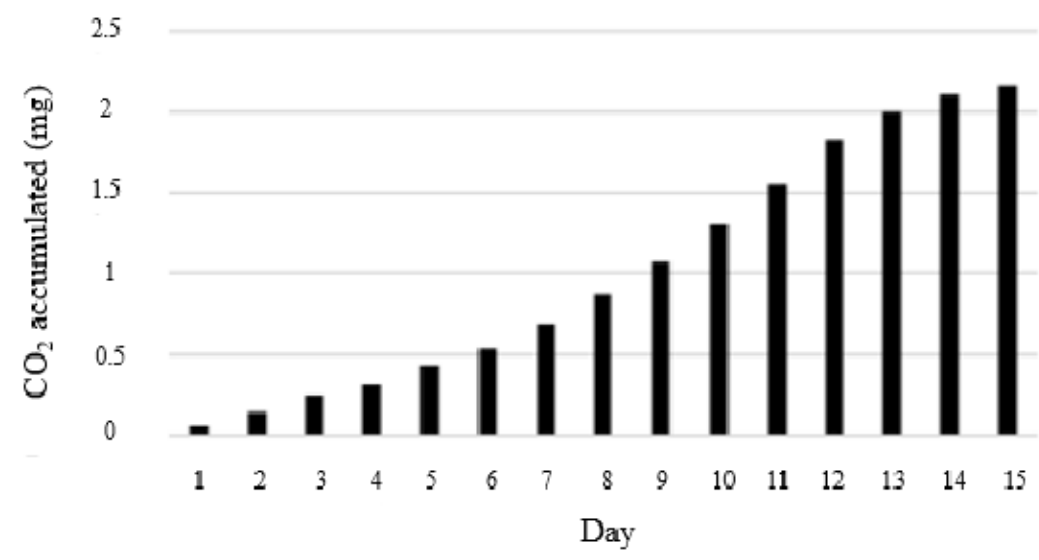

Figure 5. $\mathrm{CO}_{2}$ accumulated $(\mathrm{mg})$, produced during the biodegradation of the dye Reactive Black $5\left(50 \mathrm{mg} \mathrm{L}^{-1}, \mathrm{pH} 6.0\right)$ by $P$. chrysosporium cultivated in polyurethane foam cubes.

Respiration measurement directly determines the microbial activity by measuring carbon dioxide produced during microbial respiration, and, indirectly, determines the biodegradation of organic contaminants. Values shown in Figure 5 indicate that during all experiments (15 days) . chrysosporium was degrading RB5. As a diazo dye, RB5 has the presence of a nitrogen double bond in the chromophore group, and respiration values combined with visual discoloration observed seem to indicate that microorganism was degrading RB5, as a carbon and/or nitrogen source.

Enayatizamir et al. (2011) investigated RB5 degradation by $P$. chrysosporium immobilized on cubes of nylon sponge. The SS cultivation led to the best results with a discoloration percentage of $90.3 \%$ in $72 \mathrm{~h}$ for an initial RB5 concentration of $100 \mathrm{mg} \mathrm{L}^{-1}$. Their results showed that the discoloration ability of $P$. chrysosporium was greatly influenced by the support used, being the ability of $P$. chrysosporium to degrade RB5 mainly due to the secretion of the extracellular enzyme MnP.

\section{CONCLUSION}

It can be observed that the basidiomycete $P$. chrysosporium was the most effective for RB5 dye discoloration, besides having been the fungus studied with better radial growth speed, reaching the average value of $9.712 \mathrm{~mm} \mathrm{day}^{-1}$ in Petri dish. The adsorption test has proved that polyurethane foam has great capacity in the retention of the RB5 dye, with efficiency in adsorption of $92.4 \%$, equivalent to $46.2 \mathrm{mg}$ of dye of a solution with initial concentration at 50 $\mathrm{mg} \mathrm{L}^{-1}$ and $\mathrm{pH}$ 6.0. It was possible to ascertain that the maximum concentration condition (50 $\mathrm{mg} \mathrm{L}^{-1}$ ) of the dye solution RB5 and minimum $\mathrm{pH}$ ( $\mathrm{pH}$ 6.0) was favorable for the development of this research, since the optimal $\mathrm{pH}$ value for maximum adsorption also favored the development of the $P$. chrysosporium.

With the use of the respirometric technique, it was possible to observe the increase in the amount of $\mathrm{CO}_{2}$ produced during the inoculation, reaching the accumulated value on the last day 
of monitoring of $2.16 \mathrm{mg}$ of $\mathrm{CO}_{2}$. It is concluded that the P. chrysosporium can efficiently degrade the RB5 dye adsorbed in polyurethane foam, using it as the only source of nutrients.

\section{ACKNOWLEDGMENTS}

The authors thank the financial support granted by the Brazilian funding agencies CAPES and CNPq. Thanks also to the multi-user laboratories - LAMEAA and LAMAQ.

\section{REFERENCES}

ABNT. NBR 14283:1999 - Resíduos em solos: Determinação da biodegradação pelo método respirométrico. Rio de Janeiro, 1999.

AHMAD, M. A.; RAHMAN, N. K. Equilibrium, kinetics and thermodynamic of Remazol Brilliant Orange 3R dye adsorption on coffee husk-based activated carbon. Chemical Engineering Journal, v. 170, n. 1, p. 154-161, 2011. https://doi.org/10.1016/j.cej.2011.03.045

BARTHA, R.; PRAMER, D. Features of a flask and method for measuring the persistence and biological effects of pesticides in soil. Soil Science, v. 100, n. 1, p. 68-70, 1965.

BILAL, M.; ASGHER, M.; PARRA-SALDIVAR, R.; HU, H.; WANG, W.; ZHANG, X.; IQBAL H. M. N. Immobilized ligninolytic enzymes: An innovative and environmental responsive technology to tackle dye-based industrial pollutants - A review. Science of $\begin{array}{llllll}\text { The Total Environment, v. 576, p. } 2017 . & \end{array}$ https://doi.org/10.1016/j.scitotenv.2016.10.137

BONUGLI-SANTOS, R. C.; VIEIRA, G. A. L.; COLLINS, C.; FERNANDES, T. C. C.; MORALES, M. A. M.; MURRAY, P.; BERLINCK, R. G. S.; SETTE, L. D. Avaliação dos metabólitos e da taxa de mutagenicidade durante a degradação do corante têxtil Preto Reativo 5 pelo fungo marinho Peniophora sp. In: CONGRESSO BRASILEIRO DE MICROBIOLOGIA, 27. 2013, Natal. Anais[...] São Paulo: SBM, 2013.

ENAYATIZAMIR, N.; TABANDEH, F.; RODRÍGUEZ-COUTO, S.; YAKHCHALI, B.; ALIKHANI, H. A.; MOHAMMADI, L. Biodegradation pathway and detoxification of the diazo dye Reactive Black 5 by Phanerochaete chrysosporium. Bioresource

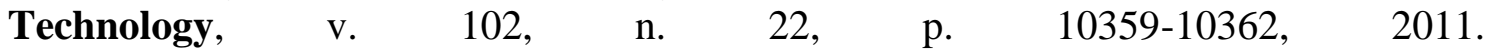
https://doi.org/10.1016/j.biortech.2011.08.130

FAN, J.; GUO, Y.; WANG, J.; FAN, M. Rapid decolorization of azo dye methyl orange in aqueous solution by nanoscale zerovalent iron particles. Journal of Hazardous Materials, v. 166, n. 2, p. 904-910, 2009. https://doi.org/10.1016/j.jhazmat.2008.11.091

GÓES, M. M.; KELlER, M.; MASIERO OLIVEIRA, V.; VILLALOBOS, L. D. G.; MORAES, J. C. G.; CARVALHO, G. M. Polyurethane foams synthesized from cellulosebased wastes: Kinetics studies of dye adsorption. Industrial Crops and Products, v. 85, p. 149-158, 2016. https://doi.org/10.1016/j.indcrop.2016.02.051

KUNZ, A.; PERALTA-ZAMORA, P.; MORAES, S. G. D.; DURÁN, N. Novas tendências no tratamento de efluentes têxteis. Química Nova, v. 25, p. 78-82, 2002. http://dx.doi.org/10.1590/S0100-40422002000100014 
MALL, I. D.; SRIVASTAVA, V. C.; AGARWAL, N. K. Removal of Orange-G and Methyl Violet dyes by adsorption onto bagasse fly ash - kinetic study and equilibrium isotherm analyses. Dyes and Pigments, v. 69, n. 3, p. 210-223, 2006. https://doi.org/10.1016/j.dyepig.2005.03.013

MIYASHIRA, C. H.; TANIGUSHI, D. G.; GUGLIOTTA, A. M.; SANTOS, D. Y. A. C. Comparison of radial growth at of the mutualistic fungus of Atta sexdens rubropilosa forel in two culture media. Brazilian Journal of Microbiology, v. 41, n. 2, p. 506-511, 2010. http://dx.doi.org/10.1590/S1517-83822010000200035

MORI, M.; CASSELLA, R. J. Estudo da sorção do corante catiônico violeta cristal por espuma de poliuretano em meio aquoso contendo dodecilsulfato de sódio. Química Nova, v. 32, p. 2039-2045, 2009. http://dx.doi.org/10.1590/S0100-40422009000800011

MUTHUKUMARAN, P.; ARAVIND, J.; THIRUMURUGAN, A.; SRIDHAR, S.; BALAN, R.; INDUMATHI, P. Screening, Isolation and Development of Fungal Consortia with Textile Reactive Dyes Decolorizing Capability. Springer International Publishing, 2017. https://dx.doi.org/10.1007/978-3-319-48439-6_22

OTTONI, C. A.; SANTOS, C.; KOZAKIEWICZ, Z.; LIMA, N. White-rot fungi capable of decolourising textile dyes under alkaline conditions. Folia Microbiologica, v. 58, n. 3, p. 187-193, 2013. https://doi.org/10.1007/s12223-012-0196-4

PERMPORNSAKUL, P.; PRASONGSUK, S.; LOTRAKUL, P.; EVELEIGH, D.; KOBAYASHI, D.; IMAI, T.; PUNNAPAYAK, H. Biological treatment of Reactive Black 5 by resupinate white rot fungus Phanerochaete sordida PBU 0057. Polish Journal of Environmental Studies, v. 25, n. 3, p. 1167-1176, 2016. https://dx.doi.org/10.15244/pjoes/61625

PIRT, S. J. Principles of Microbe and Cell Cultivation. New York: Halsted Press, 1976. 274 p. https://doi.org/10.1002/aic.690220342

RADHA, K.V.; REGUPATHI, I.; ARUNAGIRI, A.; MURUGESAN, T. Decolorization studies of synthetic dyes using Phanerochaete chrysosporium and their kinetics. Process $\begin{array}{lllllll}\text { Biochemistry, } & \text { v. } & 40, & \text { n. } & 10, & \text { p. } & 3337-3345,\end{array}$ https://doi.org/10.1016/j.procbio.2005.03.033

RÉGO, A. P. J.; REGANHAN-CONEGLIAN, C. M.; MONTAGNOLLI, R. N. et al. CO2 production of soil microbiota in the presence of ametryne and biofertilizer. Water Air Soil Pollution, v. 225, n. 12, p. 2222-2228, 2014. https://doi.org/10.1007/s11270-0142222-4

SAFA, Y.; BHATTI, H. N.; BHATTI, I. A.; ASGHER, M. Removal of direct Red-31 and direct Orange- 26 by low cost rice husk: Influence of immobilisation and pretreatments. The Canadian Journal of Chemical Engineering, v. 89, n. 6, p. 1554-1565, 2011. https://doi.org/10.1002/cjce.20473

SHARARI, M.; ROOHANI, M.; JAHAN-LATIBARI, A.; GUILLET, A.; AUROUSSEAU, M.; SHARARI, A. Treatment of bagasse preparation effluent by Phanerochaete chrysosporium immobilized on polyurethane foam: Enzyme production versus pollution removal. Industrial Crops and Products, v. 46, p. 226-233, 2013. https://doi.org/10.1016/j.indcrop.2013.02.001 
SPIER, M. R. L.; WOICIECHOWSKI, A. S.; VANDENBERGHE, L. P.; SOCCOL C. R. Production and characterization of amylases by Aspergillus niger under SSF using agro industrials products. International Journal of Food Engineering, v. 2, p. 1-19, 2006. https://doi.org/10.2202/1556-3758.1116

STATISTA. Value of the leading 10 textile exporters worldwide in 2017, by country (in billion U.S. dollars). Available at: https://www.statista.com/statistics/236397/value-ofthe-leading-global-textile-exporters-by-country. Access: Sep 302018.

TEXTILE MATES. Business in Global Market: Present and Future. Available at: https://www.textilemates.com/textile-business-global-market-present-future/. Access: Sep 302018.

VEDRENNE, M.; VASQUEZ-MEDRANO, R.; PRATO-GARCIA, D.; FRONTANA-URIBE, B. A.; HERNANDEZ- ESPARZA, M.; ANDRÉS, J. M. A ferrous oxalate mediated photo-Fenton system: Toward an increased biodegradability of indigo dyed wastewaters. Journal of Hazardous Materials, v. 243, p. 292-301, 2012. https://doi.org/10.1016/j.jhazmat.2012.10.032

VILAR, V. J. P.; PINHO, L. X.; PINTOR, A. M. A.; BOAVENTURA, R. A. R. Treatment of textile wastewaters by solar-driven advanced oxidation processes. Solar Energy, v. 85, n. 9, p. 1927-1934, 2011. https://doi.org/10.1016/j.solener.2011.04.033

WANG, L.; YAO, Y.; ZHANG, Z.; SUN, L.; LU, W.; CHEN, W.; CHEN, H. Activated carbon fibers as an excellent partner of Fenton catalyst for dyes decolorization by combination of adsorption and oxidation. Chemical Engineering Journal, v. 251, p. 348-354, 2014. https://doi.org/10.1016/j.cej.2014.04.088

WESENBERG, D.; KYRIAKIDES, I.; AGATHOS, S. N. White-rot fungi and their enzymes for treatment of industrial dye effluents. Biotechnology Advances, v. 22, n. 1, p. 161187, 2003. https://doi.org/10.1016/j.biotechadv.2003.08.011 